\title{
Islamic banking development and economic growth: a case of Indonesia
}

\section{Meri Anggraini}

PT.Telkom Indonesia

Corresponding author: meri_yugo94@yahoo.co.id

\author{
Article History \\ Received, 23 April 2019 \\ Revised 1, 10 May 2019 \\ Revised 2, 23 May 2019 \\ Accepted, 26 May 2019
}

\begin{abstract}
Purpose: In this research, an attempt has been conducted to explore the relation between Islamic banking development and economic growth of Indonesia over the periods of 2003-2014
\end{abstract}

Methodology: Two models have been formulated which are financing and deposit models to indicate the relation. The analysis are using unit root test, cointegration test, and Granger causality test within the context of VECM framework. For this purpose, financing and deposit are used as a measure of Islamic Banking development, while gross domestic product (GDP) and gross fixed capital formation (GFCF) used the indicators of economic growth.

Findings: The results show that there is bi-directional causality between financing and GDP also deposit and GDP reflecting the bi-directional causality between Islamic banking development and economic growth. Further results show that there is significant short-run and long-run causality running from Islamic banking development to economic growth so as short-run and long-run causality running from economic growth to Islamic banking development

Originality/contributions: This is the first study to used Islamic banks in Indonesia that are listed in Bank of Indonesia in 2003-2014.

Keywords: Islamic banking development, economic growth, Indonesia, Vector Error Correction Model

\section{Cite this:}

Anggraini, M. (2019). Islamic banking development and economic growth: a case study of Indonesia. Asian Journal of Islamic Management, 1(1), 51-65. DOI: 10.1108/AJIM.vol1.iss1.art5

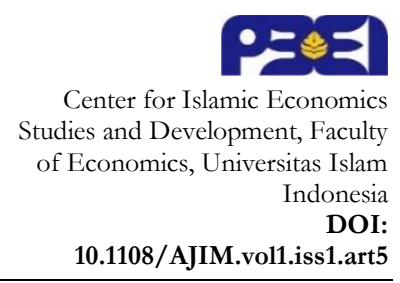

\section{Introduction}

The development of Islamic Banking in Indonesia is getting better from year to year. After the enactment of act 21 of 2008 about Islamic Banking, the development of national Islamic Banking Industry were starting to have more appropriate law basis that push the development even more. In the last five years, the average growth of financing is $38.5 \%$ per year (Financial Services Authority, 2015).

It is in line with the high rate of economic growth of Indonesia from year to year, which constantly increase. Unlike other countries, which have lower and unstable gross domestic product (GDP) as the measurement of economic growth. It showed the extensive transformation in many aspects, including the rapid development of Islamic banking which has provided a more resilience formation into the Indonesia economic development today (Abduh and Omar, 2012). 
Moreover, Abduh and Omar (2012) found that it is not just the Islamic banking development that has influenced the economic growth but vice versa. The economic growth has influenced the Islamic banking development by stimulating the demand for external capital to expand business and to follow the economic growth itself.

Some recent articles and theoretical papers have discussed about the link between Islamic banking financial and economic growth globally. Generally, they concluded that in the short run and long run, Islamic banking financial has influence on the economic growth. However, the empirical studies that have been conducted in this field still lack on the sufficient works particularly in the case of Indonesia. Not like other Islamic countries, based on the classification, Indonesia is classified in the second group which does not forbid interest rate-based banking-system. The journal of Abduh and Omar (2012) is used as the main reference in this research that has similarities in the case of Indonesia. Meanwhile the period is lengthened from Q1:2003-Q4:2014 due to the availability of the data. The method and variable are modified in reference to another journal by Al-Oqool1, Okab, and Bashayreh (2012) using two models within the context of VECM framework (financing and deposit).

The objective of paper is to narrow the gap of literature by examining the short run and the long run causality between Islamic banking and economic growth, particularly in the context of Indonesia, using unit root test, co-integration test, and granger causality test.

\section{Literature Review and Hypotheses Development}

\section{The Link between Islamic Banking Development and Economic Growth}

The link between Islamic banking development and economic growth has long been a major subject in the field of economic development. The financial sector-one of it is Islamic banking-can support the economic growth if it is able being a good financial intermediaries which move the parties with financial excess to the parties with financial shortage. When the financial sector is more developed, more financial resources can be allocated into productive use, and more physical capital can be formed which can contribute positively to economic growth.

Farahani, and Dastan (2013) used empirical evidence to examine the role of Islamic banks' financing on economic performance of selected countries (Malaysia, Indonesia, Bahrain, UAE, Saudi Arabia, Egypt, Kuwait, Qatar and Yemen).The results generally signify that, in the long run, Islamic banks' financing is positive and significantly correlated with economic growth and capital accumulation in these countries. The results obtained from the Granger causality test reveal a positive and statistically significant relationship between economic growth and Islamic banks' financing in the short run and in the long run. It also found that the long run relationship is stronger than the short run relationship.

Abduh and Omar (2012) examined the short-run and the long-run relationships between Islamic banking development and economic growth in the case of Indonesia. The results demonstrate a significant relationship in short-run and long-run periods between Islamic financial development and economic growth. The relationship, however, is neither Schumpeter's supplyleading nor Robinson's demand-following. It appears to be bi-directional relationship.

Based on the theoretical review, generally researchers found that there is causality between Islamic banking development and economic growth in the short-run and in the long-run. Specifically, the hypothesis will be formulated into short-run and long-run causality with two major hypothesis and eight minor hypothesis.

\section{The Causality between Islamic Banking Development and Economic Growth in the short-run}

Some previous researches found that there is a short-run causality between Islamic banking development and economic growth. Farahani and Dastan (2013) revealed statistically significant relationship between economic growth and Islamic banks' financing in the short run. Another research, conducted by Abduh and Omar (2012), found a significant relationship in short-run 
periods between Islamic financial development and economic growth. In the same year, Farahani, Yazdan and Sadr, Hossein (2012) also found a significant relationship in short-run periods between Islamic financial development and economic growth. Based on the findings above, it is proved that there is Islamic banking development and economic growth in the short-run.

$\mathrm{H}_{1}$ : there is causality between Islamic banking development and economic growth in the short-run.

Farahani, Yazdan, Sadr, and Hossein (2012) find that Islamic bank financing have significant impact on the changes in income. It is clear that in general that in short- run Islamic banks' financing is an important ingredient for economic development. These findings show that there is causality between financing and gross domestic product in the short-run.

$\mathrm{H}_{1 \mathrm{a}}$ : There is significant causality between financing and gross domestic product in the short-run.

Furqany and Mulyani (2009) stated that as increase in Islamic bank financing stimulates an entrepreneurial response in the productive sectors and promotes more investments, at the same time, more investment in the country facilitates Islamic banking to develop further. This research confirm that there is causality between financing and gross fixed capital formation in the short-run. $\mathrm{H}_{1 \mathrm{~b}}$ : There is significant causality between financing and gross fixed capital formation in the short-run.

Ogege and Shiro (2013) used least squares (OLS) two-stage approach. The structural analysis was done using the Impulse Response Analysis and Forecast Error Variance Decomposition to trace the one-time shock to one of the innovations in the current and future values of the exogenous variables. Empirical evidence emerges that money deposit banks in Nigeria was found to respond to economic growth. This imply that there is causality between deposit and economic growth in the short-run which in this research gross domestic product was used as the measure of economic growth.

$\mathrm{H}_{1 \mathrm{c}}$ : There is significant causality between deposit and gross domestic product in the short-run.

The research result of Omanklahen (2012) shows that commercial banks deposit liabilities only have immediate impact on capital formation. Furqani and Mulyany (2009) found that in the short-run only fixed investment that granger cause Islamic bank to develop. These findings show that in the short-run, there is causality between deposit and gross fixed capital formation.

$\mathrm{H}_{1 \mathrm{~d}}$ : There is significant causality between deposit and gross fixed capital formation in the short-run.

\section{The Causality between Islamic Banking Development and Economic Growth in the long-run}

Besides the causality between Islamic banking development and economic growth in the short-run, more researcher found that there is long-run causality too. Farahani and Dastan (2013) revealed statistically significant relationship between economic growth and Islamic banks' financing in the long run. It also found that the long run relationship is stronger than the short run relationship. Other researchs by Abduh and Omar (2012), Ali Al-Oqool1, Okab, and Bashayreh (2012), also Farahani, Yazdan and Sadr, Mohammad Hossein (2012) found significant relationship in long-run periods between Islamic financial development and economic growth. So, it is proved that there is causality between Islamic banking development and economic growth in the long-run.

$\mathrm{H}_{2}$ : there is causality between Islamic banking development and economic growth in the long-run.

Farahani, Yazdan, Sadr, and Hossein (2012) found that in the long-run, Islamic bank's financing is positive and significantly correlated with economic growth which measured by GDP. These findings show that in the long-run, there is causality between financing and gross domestic product.

$\mathrm{H}_{2 \mathrm{a}}$ : There is significant causality between financing and gross domestic product in the long-run. 
Farahani, Yazdan, Sadr, and Hossein (2012) The results generally show that in the long run, Islamic bank's financing is positive and significantly correlated with capital accumulation. These results reveal that improvement of the Islamic financial system in these countries may benefit economic development and it is important in the long run for economic welfare. Farahani and Dastan (2013) Real gross capital formation has a positive and statistically significant impact on Islamic banks' financing, indicative of their complementarily. This finding prove that there is longrun causality between financing and gross fixed capital accumulation.

$\mathrm{H}_{2 b}$ : There is significant causality between financing and gross fixed capital formation in the long-run.

Al-Oqool, Okab, and Basyareh (2014) the relation appears to be unidirectional relation between gross domestic product and deposit. Ogege and Shiro (2012) investigate the long relationship between deposit money bank and economic growth in the Nigerian context from 1974 to 2010. The deposit money banks variables exert a modest influence on the GDP. Furqani and Mulyany (2009) found that in the long-run, there is evidence of a bidirectional relationship between Islamic bank which measured by financing and fixed investment. This shows that there is causality between These findings imply that there is long-run causality between deposit and gross domestic product. $\mathrm{H}_{2 c}$ : There is significant causality between deposit and gross domestic product in the long-run.

Omankhanlen (2012) the role of deposit is reflected in capital formation through increased capital stock and the impact it makes on the capacity for an economy to generate more and higher incomes. In other word, in the long-run, there is causality between deposit and gross fixed capital formation.

$\mathrm{H}_{2 \mathrm{~d}}$ : There is significant causality between deposit and gross fixed capital formation in the long-run.

\section{Theoretical Framework}

\begin{tabular}{|c|c|c|}
\hline $\begin{array}{l}\text { Islamic Banking } \\
\text { Development } \\
\text { - Financing } \\
\text { - Deposit }\end{array}$ & 4 & $\begin{array}{l}\text { Economic Growth } \\
\text { - Gross Domestic } \\
\text { Product (GDP) } \\
\text { - Gross Fixed Capital } \\
\text { Formation (GFCF) }\end{array}$ \\
\hline
\end{tabular}

Figure 1. Theoretical Framework

\section{Research Methods}

\section{Population and Sample}

The population of this research is the Islamic banks in Indonesia. The selection of the sample is using the purposive sampling method based on the availability of the data. The sample is Islamic banks in Indonesia that are listed in Bank of Indonesia in 2003-2014.

\section{Data Collection Method}

This study is a quantitative study using historical data resources. The type of data that is used is secondary data that are obtained from some sources, which are:

1. Economic growth quarterly data period Q1:2003-Q4:2014 from the website of Statistics Indonesia (BPS)

2. Islamic bank statistical data period Q1:2003-Q4:2014 from the website of Financial Service Authority (OJK) 


\section{Analysis Technique}

\section{Model specification}

One of the most important issues in assessing the causality relation between Islamic banking and economic growth is how to obtain satisfactory empirical indicators of this issue. Proceeding from the literature review, this study has chosen, in line with Al-qool, Okab, and Bashayreh (2014), relation between Islamic banking and economic growth may be specified through the following models:

$$
\begin{aligned}
& \text { a-Financing model: } \\
& L G D P_{t}=\gamma_{0}+\gamma_{1} \text { LFINC }_{t}+e_{1 a} \\
& \text { LFINC }_{t}=\theta_{0}+\theta_{1} L_{G D P_{t}+e_{2 a}} \quad \text { (1-b) } \\
& L G F C F_{t}=\tau_{0}+\tau_{1} \text { LFINC }_{t}+e_{3 a} \quad \text { (1-c) } \\
& L_{F I N C}=\chi_{0}+\chi_{1} L_{G F C F}+e_{4 a} \\
& \text { b-Deposits model: } \\
& L G D P_{t}=a_{0}+a_{1} L D E P T t+e_{1 b} \\
& L D E P T_{t}=\beta_{0}+\beta_{1} L G D P t+e_{2 b} \quad \text { (2-b) } \\
& L G F C F_{t}=v_{0}+v_{1} L D E P T t+e_{3 b} \\
& L D E P T_{t}=\varepsilon_{0}+\varepsilon_{1} L G F C F t+e_{4 b}
\end{aligned}
$$

Where, LGDP and LGFCF are the natural logarithm of gross domestic product (GDP) and gross fixed capital formation (GFCF) as the indicators of economic growth. LFINC and LDEPT are the natural logarithm of total financing and total deposits respectively as a measure of Islamic banking development. $\left(a^{\prime} s, \beta^{\prime} s, \varepsilon^{\prime} s, \delta^{\prime} s, \chi^{\prime} s, \tau^{\prime} s, \gamma^{\prime} s, \theta^{\prime} s\right)$ are coefficients to be determined and $\left(e_{1 a}\right.$, $\left.e_{2 a}, e_{3 a}, e_{4 a}, e_{1 b}, e_{2 b}, e_{3 b}, e_{4 b}\right)$ error terms.

\section{Econometric technique}

The econometric technique applied in this research consists of three sequential steps. First is to test the stationarity of GDP, GFCF, FINC and DEPT series. Second is to detect the existence of co-integration relation between variables. Third is to analyze the Granger causality between economic growth and Islamic banking development in Indonesia.

a. Unit Root Test

To get unbiased results in time series analysis, all-time series under concerned should not contain unit root (stationary). As Newbold and Granger (1974), states that if a series have unit root this leads to produce spurious result. In order to test for stationary, this research employed Augmented Dickey-Fuller (ADF) test (Dickey \& Fuller, 1979). ADF utilized with the inclusion of a constant and a trend for each time series variable. In ADF, researcher tested the null hypothesis that the series have unit root (non-stationary), against the alternative one that the series is stationary (have no unit root) by comparing the calculated ADF $\tau$ (tua)-statistics value with the critical $\tau$-statistics value obtained from McKinnon's Table (Enders, 1995). Non stationary series leads to difference the time series until stationary is achieved, if the nonstationary time series become stationary after differences it (d) times, then we can say that the series is integrated of order (d), i.e. I(d).

b. Co-Integration Test

The Johansen approach developed by Johansen and Jesulius (1990) and Johansen (1991) used to investigate the possible long-run relation existence between the study variables. Johansen approach uses two test statistics, as suggested by Oseterwald-Lenum (1992) to determine the number of co-integrating vectors. These are the trace test and the maximum Eigen value test, represented by equation (3) and (4). 


$$
\begin{aligned}
& \lambda_{\text {trace }}(r)=-T+\sum_{i=(r+1)}^{n} \ln (1-\lambda i) \\
& \lambda_{\max }(r, r+1)=-T \ln \left(1-\lambda_{r+1}\right)
\end{aligned}
$$

Where $\lambda_{\mathrm{i}}$ is the ith shows the estimated values of the characteristic roots, in assuming that the series are $\mathrm{I}(1)$. $T$, is the number of observations and $r$, is the rank of the vector matrix.

This research tested the null hypothesis of Trace test that there is at most $(r)$ co-integrated relation against the alternative one that there are more than $(r)$ co-integrated relations. In other words, a rejection of the null hypothesis means that there are more than $(r)$ co-integrated relations. The Trace test rejects the null hypothesis if the trace statistics exceeds the critical value. On the other hand, we test the null that there is $(r)$ co-integrated relation versus $(r+1)$ co-integrated relations. The test rejects the null hypothesis if the Eigen value test statistics exceeds the respective critical value. If the null hypothesis for both statistics is rejected, this indicates that there is one co-integrated relation among the variables under testing.

c. Granger Causality based on VECM Framework

Granger causality concept Granger, (1969) states that if two variables (say: X, Y) are cointegrated than each is individually integrated of order one, i.e. I(1). Then either X causes $\mathrm{Y}$ if and only if the past values of $\mathrm{X}$ help to predict the changes of $\mathrm{Y}$ or $\mathrm{Y}$ causes $\mathrm{X}$ if and only if the past values of $Y$ help to predict the changes of $X$. This test has the aim to know whether there is short-run causality between variables and also the direction of causality. Assuming the presence of co-integrating vector among the variables in finance and deposits models, the Granger causality test based on the VECM can be formulated as follows:

$$
\begin{aligned}
& \text { a-Financing model: } \\
& \Delta L G D P_{t}=\gamma_{0}+\sum_{i=1}^{p} \quad \gamma_{1} \Delta L G D P_{t-i}+\sum_{i=1}^{p} \quad \gamma_{2} \Delta L F I N C_{t-i} \\
& +\delta_{1} \mathrm{ECT}_{\mathrm{t}-1}+\mathrm{u}_{\mathrm{t}} \\
& \Delta \text { FINC }_{t}=\theta_{0}+\sum_{i=1}^{p} \quad \theta_{1} \Delta \operatorname{LFINC}_{t-i}+\sum_{i=1}^{p} \quad \theta_{2} \Delta L G D P_{t-i} \\
& +\delta_{2} \mathrm{ECT}_{\mathrm{t}-1}+\mathrm{u}_{\mathrm{t}} \\
& \Delta L G F C F_{t}=\tau_{0}+\sum_{i=1}^{p} \quad \tau_{1} \Delta L G F C F_{t-i}+\sum_{i=1}^{p} \quad \tau_{2} \Delta L F I N C_{t-i} \\
& +\delta_{3} \mathrm{ECT}_{\mathrm{t}-1}+\mathrm{u}_{\mathrm{t}} \\
& \Delta L F I N C_{t}=\chi_{0}+\sum_{i=1}^{p} \quad \chi_{1} \Delta L F I N C_{t-i}+\sum_{i=1}^{p} \quad \chi_{2} \Delta L G F C F_{t-i} \\
& +\delta_{4} \mathrm{ECT}_{\mathrm{t}-1}+\mathrm{u}_{\mathrm{t}} \\
& \text { b-Deposits model: } \\
& \Delta L G D P_{t}=a_{0}+\sum_{i=1}^{p} \quad a_{1} \Delta L G D P_{t-i}+\sum_{i=1}^{p} \quad a_{2} \Delta L D E P T_{t-i} \\
& +\delta_{5} \mathrm{ECT}_{\mathrm{t}-1}+\mathrm{u}_{\mathrm{t}} \\
& \triangle L D E P T_{t}=\beta_{0}+\sum_{i=1}^{p} \quad \beta_{1} \Delta L D E P T_{t-i}+\sum_{i=1}^{p} \quad \beta_{2} \Delta L D E P T_{t-i} \\
& +\delta_{6} \mathrm{ECT}_{\mathrm{t}-1}+\mathrm{u}_{\mathrm{t}} \\
& \Delta L G F C F_{t}=v_{0}+\sum_{i=1}^{p} \quad v_{1} \Delta L G F C F_{t-i}+\sum_{i=1}^{p} \quad v_{2} \Delta L D E P T_{t-i} \\
& +\delta_{7} \mathrm{ECT}_{\mathrm{t}-1}+\mathrm{u}_{\mathrm{t}} \\
& \triangle L D E P T_{t}=\varepsilon_{0}+\sum_{i=1}^{p} \quad \varepsilon_{1} \Delta L D E P T_{t-i}+\sum_{i=1}^{p} \quad \varepsilon_{2} \Delta L G F C F_{t-i} \\
& +\delta_{8} \mathrm{ECT}_{\mathrm{t}-1}+\mathrm{u}_{\mathrm{t}}
\end{aligned}
$$

Where, LFINC and LDEPT are the natural log of total finance and total deposits of Islamic banking respectively. ECTt-1 is the error correction term contains the long-run information, since it is derived from the long-run integrated relationship. To investigate the long-run causality the following hypotheses are tested: 
1. FINC does not Granger causes RGDP if $\mathrm{H}_{0}: \gamma_{2}=0$ against the alternative $\mathrm{H} \alpha: \gamma_{2} \neq 0$ FINC Granger causes RGDP. (Equation 5-a);

2. RGDP does not Granger causes FINC if $\mathrm{H}_{0}: \theta_{2}=0$ against the alternative $\mathrm{H} \alpha: \theta_{2} \neq 0$ RGDP Granger causes FINC. (Equation 5-b);

3. FINC does not Granger causes GFCF if $\mathrm{H}_{0}: \tau_{2}=0$ against the alternative $\mathrm{H} \alpha: \tau_{2} \neq 0$ FINC Granger causes GFCF. (Equation 5-c);

4. GFCF does not Granger causes FINC if $\mathrm{H}_{0}: \chi_{2}=0$ against the alternative $\mathrm{H} \alpha: \chi_{2} \neq 0$ GFCF Granger causes FINC. (Equation 5-d);

5. DEPT does not Granger causes RGDP if $\mathrm{H}_{0}: \alpha_{2}=0$ against the alternative $\mathrm{H} \alpha:{ }_{2} \neq 0$ DEPT Granger causes RGDP. (Equation 6-a);

6. RGDP does not Granger causes DEPT if $\mathrm{H}_{0}: \beta_{2}=0$ against the alternative $\mathrm{H} \alpha: \beta_{2} \neq 0$ RGDP Granger causes DEPT. (Equation 6-b);

7. DEPT does not Granger causes GFCF if $\mathrm{H}_{0}: \mathrm{U}_{2}=0$ against the alternative $\mathrm{H} \alpha: \mathrm{v}_{2} \neq 0$ DEPT Granger causes GFCF. (Equation 6-c);

8. GFCF does not Granger causes DEPT if $\mathrm{H}_{0}: \varepsilon_{2}=0$ against the alternative $\mathrm{H} \alpha: \varepsilon_{2} \neq 0$ GFCF Granger causes DEPT. (Equation 6-d);

The magnitude and statistical significance of ( $\delta$ 's) in each ECT equation implies long-run causal relationship and measures the tendencies of each variable to return to the equilibrium. On other words the stability of long-run equilibrium can also be judged from the sign and significance of the ECT as if it is negatively significant, it shows convergence towards the equilibrium i.e. a stable long-run equilibrium, While the short-run relationships will be captured through the individual coefficients (i.e. $1, \gamma 2, \theta 1, \theta 2, \tau 1, \tau 2, \chi^{1}, \chi^{2}, a 1, a 2, \beta 1, \beta 2,01$, $02, \varepsilon 1, \varepsilon 2)$ of the difference terms. The Wald test of the explanatory variables indicates the short-run causal effects, and the direction of causality.

\section{Results}

\section{Descriptive Statistics of Research Variables}

This descriptive statistics analysis will explain the description of research variable data. The descriptive statistics elaborates the character of research variables. This analysis contains the information such as sum of population, maximum and minimum value, mean and standard deviation of each research variable. The sample of this research consists of 48 data of four timeseries variables which are LFINC, LDEPT, LGDP, and LGFCF quarterly through 2003-2014. The table below is the descriptive analysis of each variable:

Table 4.1. The Descriptive Statistics of Research Variables

\begin{tabular}{lcccc}
\hline & LFINC & LDEPT & LGDP & LGFCF \\
\hline Mean & 10.53148 & 10.53428 & 13.19029 & 11.72359 \\
Median & 10.56487 & 10.53053 & 13.18877 & 11.73992 \\
Maximum & 12.19237 & 12.29160 & 13.52134 & 12.14815 \\
Minimum & 8.206038 & 8.117909 & 12.86552 & 11.21646 \\
Std. Dev. & 1.162112 & 1.183286 & 0.198914 & 0.268792 \\
Jarque-Bera & 2.118532 & 2.289165 & 3.088987 & 2.522511 \\
Probability & 0.346710 & 0.318357 & 0.213420 & 0.283298 \\
Observations & 48 & 48 & 48 & 48 \\
\hline
\end{tabular}

The basic statistical values of the variables are calculated in the first phase of this study. Based on the data of Table 4.1, the mean value of financing (LFINC) is 10.53148. The standard deviation value is 1.162112. Meanwhile the data value spreads from the minimum value 8.206038 to the maximum value 12.19237 with the median 10.56487 . 
At the second column of the table, the mean value of deposit (LDEPT) is 10.53428 . The standard deviation value is 1.183286 . Meanwhile the data value spreads from the minimum value 8.117909 to the maximum value 12.29160 with the median 10.53053 .

For gross domestic product (LGDP), the mean value is 13.19029. The standard deviation value is 10.198914 . Meanwhile the data value spreads from the minimum value 12.86552 to the maximum value 13.52134 with the median 13.18877 .

For gross fixed capital formation (LGFCF), the mean value is 11.72359. The standard deviation value is 10.268792. Meanwhile the data value spreads from the minimum value 11.21646 to the maximum value 12.14815 with the median 11.73992 .

Results obtained from Jarque-Bera statistic confirm that none of the series are normally distributed. The probabilities of LFINC (0.346710), LDEPT (0.318357), LGDP (0.213420), and LGFCF (0.283298) are more than the 5\% percent level of significance. The null hypotheses of Jarque-Bera test (data follow normal distribution) are rejected in all the cases at $5 \%$ percent level of significance.

\section{Unit Root Test Result}

The null hypotheses of Augmented Dickey-Fuller Test (ADF Test) is that the data consist unit roots or the data is not stationer with the criterion if the $t$-statistic is higher than the critical value means the null hypotheses is rejected which mean the data is already stationer. ADF unit root test is utilized the results are summarized in Table 4.2. The result indicates that all variables are stationary in the first difference:

Table 4.2. Stationary Test Result

\begin{tabular}{lcc}
\hline \multirow{2}{*}{ Variables } & \multicolumn{2}{c}{ ADF $\tau$-Statistics } \\
\cline { 2 - 3 } & Level & First Difference \\
\hline LGDP & -2.596662 & -12.03204 \\
LGFCF & -0.905780 & -3.800844 \\
LFINC & -3.231147 & -4.917125 \\
LDEPT & -2.995309 & -6.325958 \\
$1 \%$ Critical Value & -3.577723 & -3.581152 \\
$5 \%$ Critical Value & -2.925169 & -2.926622 \\
$10 \%$ Critical Value & -2.600658 & -2.601424 \\
\hline
\end{tabular}

Note: Critical $\tau$-Statistic values obtained from Davidson and MacKinnon (1993).

\section{Co-Integration Test Result}

Before the data proceed with co-integration test, the optimal lag length must be decided. The optimum lag length decided by comparing the value of Akaike Information (AIC). Besides that, there are others four criterion lag length indicator such as LR, FPE, SC (SIC) and HQ (HQC). The best optimum lag length is where the lag that as the most criterions. The selection of optimum lag length result analyzed in financing and deposit model in the tables 4.3.

Based on the result in table 4.3, the optimum lag length of financing model is lag 3 which supported by all criterions. Meanwhile based on the table 4.4, the optimum lag for deposit model is lag 3 as well as the optimum lag length for financing model. It is chosen since supported by most of the criterion which are LR, FPE, and AIC.

Having confirmed that all-time series are integrated of the same order, i.e., I(3) the Johansen efficient maximum-likelihood approach (Johansen, 1988) has been applied to detect independently the possibilities existence of co-integration relation among the variables under concerns. Table 4.5 that shown in appendix 1 provides Johansen co-integration results. 
Table 4.3. Selection of Optimum Lag Length: Financing Model

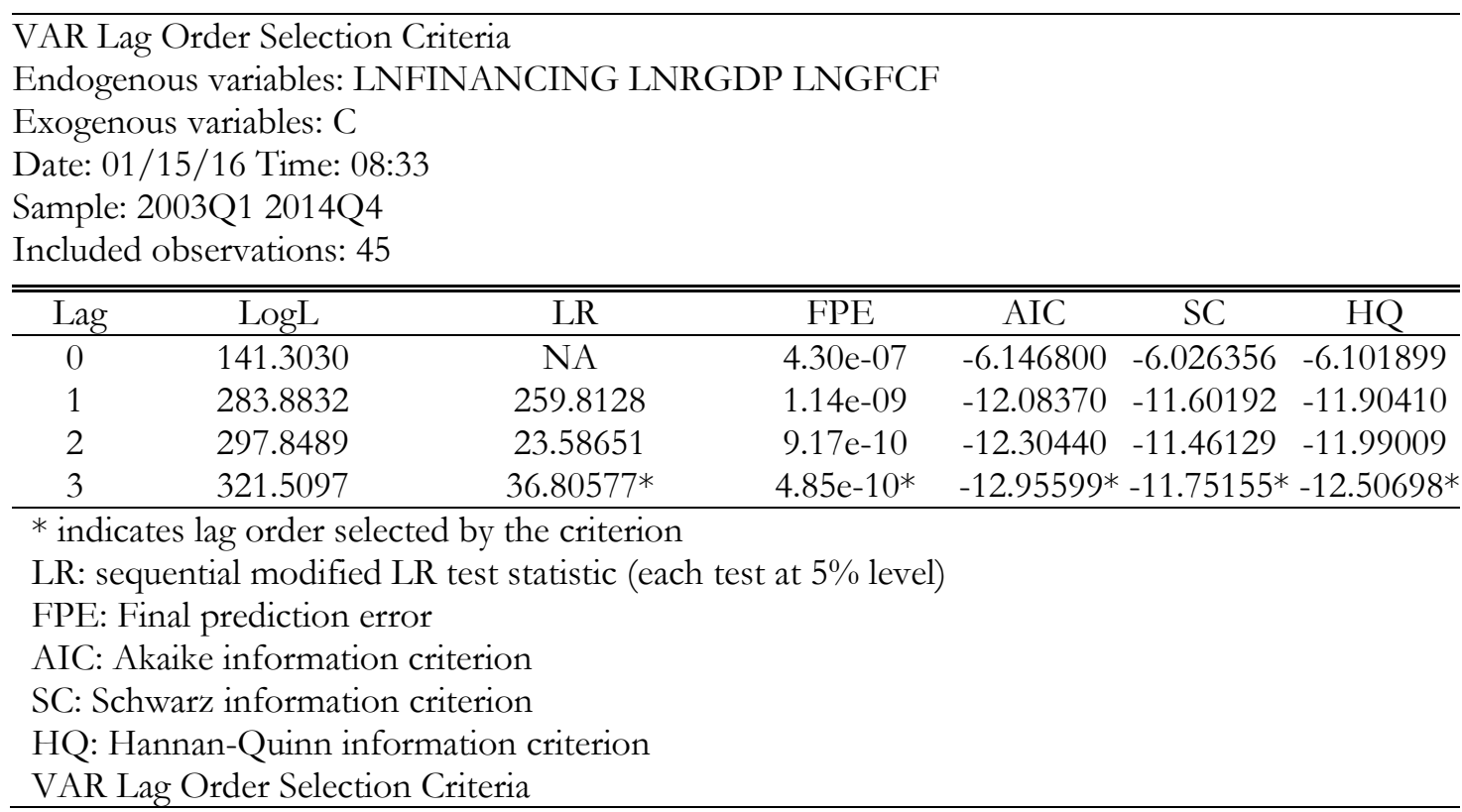

Table 4.4. Selection of Optimum Lag Length: Deposit Model

\begin{tabular}{l}
\hline VAR Lag Order Selection Criteria \\
Endogenous variables: LNDEPOSIT LNGFCF LNRGDP \\
Exogenous variables: C \\
Date: 01/15/16 Time: 08:35 \\
Sample: 2003Q1 2014Q4 \\
$\begin{array}{lllllll} \\
\text { Included observations: } 45\end{array}$ \\
\hline \hline
\end{tabular}

Based on the results in table 4.5, in the financing model, for LFINC-LGDP, the value of trace test statistics 19.34687 is bigger than the critical value 15.49471 with the significance level of $0.0125(1.25 \%)$ less than $5 \%$. The value of maximum eigenvalue statistics 19.19080 is bigger than the critical value 14.26460 with the significance level of $0.0077(0.77 \%)$ less than $5 \%$.Meanwhile, for LFINC-LGFCF, the value of trace test statistics 27.01517 is bigger than the critical value 15.49471 with the significance level of $0.0006(0.06 \%)$ less than $5 \%$. The value of maximum eigenvalue statistics 24.56589 is bigger than the critical value 14.26460 with the significance level of $0.0009(0.09 \%)$ less than $5 \%$.

In the deposit model, for LDEPT-LGDP, the value of trace test statistics 23.66117 is bigger than the critical value 15.49471 with the significance level of $0.0024(0.24 \%)$ less than $5 \%$. The value of maximum eigenvalue statistics 23.53854 is bigger than the critical value 14.26460 with the significance level of $0.0013(0.13 \%)$ less than 5\%. Meanwhile, for LDEPT-LGFCF, the value of trace test statistics 16.00752 is bigger than the critical value 15.49471 with the significance level of 
$0.0006(0.06 \%)$ less than $5 \%$. The value of maximum eigenvalue statistics 12.23341 is smaller than the critical value 14.26460 with the significance level of $0.1022(10.22 \%)$ more than $5 \%$. In this term, the result of trace statistic and maximum eigenvalue is contrary. The value of trace statistic stated that there is co-integration meanwhile the maximum eigenvalue is no co-integration. In this case, the writer refers to Lüutkepohl, Saikkonen, and Trenkleer (2001) which conclude that based on the simulations they have a preference for the trace test. This result justifies the common practice in empirical work to use either both types of tests simultaneously or apply the trace tests exclusively. So that in this case, the results is preference to the trace statistics value meaning that there is co-integration.

Based on the result above, the null hypothesis in financing model (LFINC-LGDP and LFINC-LGFCF) and deposit model (LDEPT-LGDP and LDEPT-LGFCF) are both rejected which means there are co-integration and also indication the existence of long-term relationship between variables.

\section{Causality Test Results Based on VECM}

After we confirmed that all EG and IBD measures are co-integrated, the Granger Causality test and VECM based causality tests are conducted using Johansen co-integrating vectors. The results of the Granger causality tests based on the VECM for both financing and deposits models are presented in Table 4.6 and Table 4.7.

Table 4.6. Granger Causality Test Result

\begin{tabular}{ccccc}
\hline Null Hypothesis & Obs. & F-Statistics & Prob & Causality \\
\hline GFCF cause FINC & 45 & 3.17627 & 0.0349 & Significant \\
FINC cause GFCF & 45 & 2.69686 & 0.0594 & Insignificant \\
GDP cause FINC & 45 & 5.17625 & 0.0043 & Significant \\
FINC cause GDP & 45 & 21.1005 & $3 . E-08$ & Significant \\
GFCF cause DEPT & 45 & 2.56846 & 0.0686 & Insignificant \\
DEPT cause GFCF & 45 & 3.80616 & 0.0176 & Significant \\
GDP cause DEPT & 45 & 3.32906 & 0.0120 & Significant \\
DEPT cause GDP & 45 & 4.16968 & 0.0120 & Significant \\
\hline
\end{tabular}

Based on the results of Granger causality test in the table 4.6, the null hypothesis of "LGFCF does not Granger Cause LFINC", "LGDP does not Granger Cause LFINC", "LFINC does not Granger Cause LGDP", "LDEPT does not Granger Cause LGFCF", "LGDP does not Granger Cause LDEPT", and "LDEPT does not Granger Cause LGDP" are rejected. Meanwhile the null hypothesis of "LFINC does not Granger Cause LGFCF" and "LGFCF does not Granger Cause LDEPT" cannot be rejected.

Table 4.7. Vector Error Correction Model (VECM) Results

\begin{tabular}{|c|c|c|c|c|c|}
\hline \multirow{2}{*}{ Model } & \multirow{2}{*}{ equation } & \multicolumn{2}{|c|}{ Short-run } & \multicolumn{2}{|c|}{ Long-run } \\
\hline & & $D$ & $D(-1)$ & C & $D(-1)$ \\
\hline \multirow[t]{4}{*}{ financing } & $5-a$ & $0.343319 *$ & $0.237390^{*}$ & $11.23942 *$ & $0.184785^{*}$ \\
\hline & $5-b$ & 0.199371* & $0.753822^{*}$ & $60.82435^{*}$ & 5.411697* \\
\hline & $5-c$ & -0.370175 & 0.164650 & -9.160008 & -0.243194 \\
\hline & $5-d$ & $0.331247^{*}$ & $1.159115^{*}$ & $37.66550^{*}$ & 4.111951* \\
\hline \multirow[t]{4}{*}{ deposit } & $6-a$ & $0.514751 *$ & $0.022281 *$ & $11.29469 *$ & $0.179486^{*}$ \\
\hline & $6-b$ & -0.218820 & -0.242034 & 62.92811* & $5.571476^{*}$ \\
\hline & $6-c$ & 0.740179* & $0.075197 *$ & 9.301927* & $0.229693^{*}$ \\
\hline & $6-d$ & 0.584573 & -0.079259 & 40.49717 & -4.353632 \\
\hline
\end{tabular}


Based on the results showed in table 4.7, in the financing model, equation (5-a), (5-b), and (5-d) are significant at 5\% level of significance in short-run and long-run relationship. In short-run, the interpretation of equation (5-a) is if there is increasing as much as 1 percent in financing (LFINC) then it will cause the increasing of gross domestic products (LGDP) as much as 0.022281 . The VECM value indicates that it can correct the deviation to short-run equilibrium as much as 0.343319 in every quarter (three months). The interpretation of equation (5-a) is if there is increasing as much as 1 percent in financing (LFINC) then it will cause the increasing of gross domestic products (LGDP) as much as 0.184785 . The VECM value indicates that it can correct the deviation to long-run equilibrium as much as 11.23942 in every quarter (three months).

In short-run, the interpretation of equation $(5-b)$ is if there is increasing as much as 1 percent in gross domestic products (LGDP) then it will cause the increasing of financing (LFINC) as much as 0.753822 . The VECM value indicates that it can correct the deviation to short-run equilibrium as much as 0.753822 in every quarter (three months). The interpretation of equation (5-b) is if there is increasing as much as 1 percent in gross domestic products (LGDP) then it will cause the increasing of financing (LFINC) as much as 5.411697. The VECM value indicates that it can correct the deviation to long-run equilibrium as much as 60.82435 in every quarter (three months).

In short-run, the interpretation of equation (5-d) is if there is increasing as much as 1 percent in gross fixed capital formulation (LGFCF) then it will cause the increasing of financing (LFINC) as much as 1.159115. The VECM value indicates that it can correct the deviation to short-run equilibrium as much as 0.331247 in every quarter (three months). The interpretation of equation (5-d) is if there is increasing as much as 1 percent in fixed capital formulation (LGFCF) then it will cause the increasing of financing (LFINC) as much as 4.111951. The VECM value indicates that it can correct the deviation to long-run equilibrium as much as 37.66550 in every quarter (three months).

It can be inferred from financing model that there is bi-directional short-run and long-run causalities running from LFINC to LGDP and LGDP to LFINC. Meanwhile it appears that there is uni-directional short-run and long-run causalities running from LGFCF to LFINC.

In the deposit model, equation (6-a), (6-b), and (6-c) are significant at 5\% level of significance in short-run and long-run relationship. In short-run, the interpretation of equation (6a) is if there is increasing as much as 1 percent in deposit (LDEPT) then it will cause the increasing of gross domestic products (LGDP) as much as 0.022281 . The VECM value indicates that it can correct the deviation to short-run equilibrium as much as 0.514751 in every quarter (three months). The interpretation of equation (6-a) is if there is increasing as much as 1 percent in deposit (LDEPT) then it will cause the increasing of gross domestic products (LGDP) as much as 0.179486 . The VECM value indicates that it can correct the deviation to long-run equilibrium as much as 11.29469 in every quarter (three months).

In long-run,the interpretation of equation (6-b) is if there is increasing as much as 1 percent in gross domestic products (LGDP) then it will cause the increasing of deposit (LDEPT) as much as 5.411697. The VECM value indicates that it can correct the deviation to long-run equilibrium as much as 60.82435 in every quarter (three months).

In short-run, the interpretation of equation (6-c) is if there is increasing as much as 1 percent in deposit (LDEPT) then it will cause the increasing of gross fixed capital formation (LGFCF) as much as 0.022281 . The VECM value indicates that it can correct the deviation to short-run equilibrium as much as 0.740179 in every quarter (three months). The interpretation of equation (6-c) is if there is increasing as much as 1 percent in deposit (LDEPT) then it will cause the increasing of gross fixed capital formation (LGFCF) as much as 0.229693. The VECM value indicates that it can correct the deviation to long-run equilibrium as much as 9.301927 in every quarter (three months).

It can be inferred from deposit model that there is uni-directional short-run causalities but bi-directional in the long-run causalities running from LDEPT to LGDP and LGDP to LDEPT. 
Meanwhile it appears that there is uni-directional short-run and long-run causalities running from LDEPT to LGFCF.

\section{Discussion}

Based on the co-integration test result, there is co-integrated relation between Islamic banking development measures (financing and deposit) and economic growth (GDP and GFCF). Because it fulfill the co-integration test, then Granger causality test is conducted. In this term, VECM test is applied because based on the unit root test, all of the variables are stationary at the first difference.

\section{The Causality between Islamic Banking Development and Economic Growth in the short-run}

Based on the result, it shows that there is significant causality between financing and GDP. So that $\mathrm{H}_{1 \mathrm{a}}$ can be accepted. It means that financing and GDP can influence each other at least in one direction. Beyond that, the result also shows that there is bi-directional causality between financing and GDP which means that the total financing of Islamic banking in Indonesia will affect the GDP and vice versa. This finding is in line with the previous research by Farahani, Yazdan, Sadr, and Hossein (2012). These findings show that there is causality between financing and gross domestic product in the short-run.

There is significant causality between financing and GFCF. So that $\mathrm{H}_{1 \mathrm{~b}}$ can be accepted. It means that financing and GFCF can influence each other at least in one direction. Beyond that, the result also shows that there is uni-directional causality between financing and GFCF running from GFCF to financing. This means that the gross fixed capital formation affects the total financing of Islamic banks but not in reverse. This finding is in line with the previous research by Furqany and Mulyani (2009) that found the causality between financing and gross fixed capital formation in the short-run.

There is significant causality between deposit and GDP. So that $\mathrm{H}_{1 \mathrm{c}}$ can be accepted. It means that deposit and GDP can influence each other at least in one direction. Beyond that, the result also shows that there is uni-directional causality between deposit and GDP running from deposit and GDP. This means that the total deposit of Islamic banks affects the gross domestic product but not in reverse. This finding is in line with the previous research by Ogege and Shiro (2013) which found that there is causality between deposit and economic growth in the short-run which in this research gross domestic product was used as the measure of economic growth.

There is significant causality between deposit and GFCF. So that $\mathrm{H}_{1 \mathrm{~d}}$ can be accepted. It means that deposit and GFCF can influence each other at least in one direction. Beyond that, the result also shows that there is uni-directional causality between deposit and GFCF running from deposit and GFCF. This means that the total deposit of Islamic banks affects the gross fixed capital formation but not in reverse. This finding is in line with the previous research by Omanklahen (2012) and Furqani and Mulyany (2009) which found that in the short-run, there is causality between deposit and gross fixed capital formation.

From the discussion above, all of the minor hypothesis which are $\mathrm{H}_{1 \mathrm{a}}, \mathrm{H}_{1 \mathrm{~b}}, \mathrm{H}_{1 \mathrm{c}}$, and $\mathrm{H}_{1 \mathrm{~d}}$ can be accepted. So, it can be concluded that the major hypothesis $\left(\mathrm{H}_{1}\right)$ also accepted. This means that there is causality between Islamic banking development and economic growth in the short-run. This finding is in line with the previous research by Farahani and Dastan (2013) and Abduh and Omar (2012) that found a significant relationship in short-run periods between Islamic financial development and economic growth.

\section{The Causality between Islamic Banking Development and Economic Growth in the long-run}

Based on the result, it shows that there is significant causality between financing and GDP in the long-run. So that $\mathrm{H}_{2 a}$ can be accepted. It means that financing and GDP can influence each other at least in one direction. Beyond that, the result also shows that there is bi-directional causality between financing and GDP which means that the total financing of Islamic banking in Indonesia 
will affect the GDP and vice versa. This finding is in line with the previous research by Farahani, Yazdan, Sadr, and Hossein (2012). These findings show that there is causality between financing and gross domestic product in the long-run.

There is significant causality between financing and GFCF. So that $\mathrm{H}_{2 \mathrm{~b}}$ can be accepted. It means that financing and GFCF can influence each other at least in one direction. Beyond that, the result also shows that there is uni-directional causality between financing and GFCF running from GFCF to financing. This means that the gross fixed capital formation affects the total financing of Islamic banks but not in reverse. This finding is in line with the previous research by Furqany and Mulyani (2009) that found the causality between financing and gross fixed capital formation in the long-run.

There is significant causality between deposit and GDP. So that $\mathrm{H}_{2 \mathrm{c}}$ can be accepted. It means that deposit and GDP can influence each other at least in one direction. Beyond that, the result also shows that in the long-run, GDP will affect the total deposit of Islamic banks. So, there is bi-directional causality between deposit and GDP in the long-run. This means that the total deposit of Islamic banks affects the gross domestic product but and vice versa. This finding is in line with the previous research by Ogege and Shiro (2013) which found that there is causality between deposit and economic growth in the long-run which in this research gross domestic product was used as the measure of economic growth.

There is significant causality between deposit and GFCF. So that $\mathrm{H}_{2 \mathrm{~d}}$ can be accepted. It means that deposit and GFCF can influence each other at least in one direction. Beyond that, the result also shows that there is uni-directional causality between deposit and GFCF running from deposit and GFCF. This means that the total deposit of Islamic banks affects the gross fixed capital formation but not in reverse. This finding is in line with the previous research by Omanklahen (2012) and Furqani and Mulyany (2009) which found that in the long-run, there is causality between deposit and gross fixed capital formation.

From the discussion above, all of the minor hypothesis which are $\mathrm{H}_{2 \mathrm{a}}, \mathrm{H}_{2 \mathrm{~b}}, \mathrm{H}_{2 \mathrm{c}}$, and $\mathrm{H}_{2 \mathrm{~d}}$ can be accepted. So, it can be concluded that the major hypothesis $\left(\mathrm{H}_{2}\right)$ also accepted. This means that there is causality between Islamic banking development and economic growth in the long-run. This finding is in line with the previous research by Farahani and Dastan (2013), Abduh and Omar (2012), Al-Oqool1, Okab, and Bashayreh (2012), also Farahani, Yazdan and Sadr, Hossein (2012) that found a significant relationship in the long-run periods between Islamic financial development and economic growth.

\section{Conclussion and Recomendation}

This research has attempted to explore the relation between Islamic banking development and economic growth in Indonesia over the period of 2003-2014, focusing on Granger causality effects within the context of VECM framework. For this purpose, FINC and DEPT are used as a measure of Islamic banking development, while GDP and GFCF used as indicators of economic growth.

It is found that there is causality between Islamic banking development and economic growth in the short run. Based on the financing model, there is bi-directional causality between financing and GDP. Meaning that total financing of Islamic banks affects GDP and vice versa. So that $\mathrm{H}_{1 a}$ is accepted. There is uni-directional causality between financing and GFCF running from GFCF to financing. Meaning that GFCF affects the total financing of Islamic banks. So that $\mathrm{H}_{1 \mathrm{~b}}$ is accepted.

Based on the deposit model, There is uni-directional causality between deposit and GDP running from deposit to GDP. Meaning that the total deposit of Islamic banks affects the GDP. So that $\mathrm{H}_{1 \mathrm{c}}$ is accepted. There is uni-directional causality between deposit and GFCF running from deposit to GFCF. Meaning that the total deposit of Islamic banks affects GFCF. So that $\mathrm{H}_{1 \mathrm{~d}}$ is accepted.

Based on the result above, all of the minor hypothesis are accepted. It can be concluded that the major hypothesis $\left(\mathrm{H}_{1}\right)$ can be accepted. This means that there is causality between Islamic 
banking development and economic growth in the short-run. Besides, it also found that it is bidirectional causality.

It is found that there is the causality between Islamic banking development and economic growth in the long run. Based on the financing model, there is bi-directional causality between financing and GDP. Meaning that total financing of Islamic banks affects GDP and vice versa. So that $\mathrm{H}_{2 \mathrm{a}}$ is accepted. There is uni-directional causality between financing and GFCF running from GFCF to financing. Meaning that GFCF affects the total financing of Islamic banks. So that $\mathrm{H}_{2 \mathrm{~b}}$ is accepted.

Based on the deposit model, There is bi-directional causality between deposit and GDP. Meaning that the total deposit of Islamic banks affects the GDP and vice versa. So that $\mathrm{H}_{2 \mathrm{c}}$ is accepted. There is uni-directional causality between deposit and GFCF running from deposit to GFCF. Meaning that the total deposit of Islamic banks affects GFCF. So that $\mathrm{H}_{2 \mathrm{~d}}$ is accepted.

Based on the result above, all of the minor hypothesis are accepted. It can be concluded that the major hypothesis $\left(\mathrm{H}_{2}\right)$ can be accepted. This means that there is causality between Islamic banking development and economic growth in the long-run. Besides, it also found that it is bidirectional causality.

In this part the researcher will present recommendation toward some parties who have close relation and interest toward this topic. The researcher hopes that this recommendation can give the advantage toward the improvement of government, Islamic banking in Indonesia and for the further research.

As it is found that there is bi-directional relationship between economic growth and Islamic banking development, government who has the authorities in regulate and manage the economic growth must have a good harmonization with the Islamic banking which has the important role in the development of Islamic banking itself. These two institutions can make a good economic condition by supporting each other. This can be done by encouraging the establishment of Islamic commercial banks, Islamic windows, and Islamic rural banks while at the same time encourage existing Islamic banks to establish more branches. In addition, allowing foreign Islamic banks to operate in Indonesia can also help to foster more innovation in the domestic Islamic banking industry. Indonesia also needs competent Sharia personnel and advisers apart from trained Islamic bankers. In this regard, more universities and specialized training institutes will be required to produce the required labor. Islamic banking will not be able to contribute fully to economic growth if the economy is not growing well, hence a positive economic growth will help spur Islamic banking growth further.

In order to improve this study in the future, some directions for further researches such as combining some countries which have implemented Islamic financial system for a reasonable time so that adequate number of data can be collected; use different method of analysis in order to find the robustness of the results; and comparative analysis towards countries with fully Islamic financial system and dual-banking system to find the consistency of the results.

\section{Reference}

Abduh, M., and Omar, M. A. (2012), "Islamic Banking and Economic Growth: The Indonesian Experience", International Journal of Islamic and Middle Eastern Finance and Management, Vol. 5 No. 1 pp. $35-47$

Al-Oqool, M. A., Okab, R., and Bashayreh, M. (2014), "Financial Islamic Banking Development and Economic Growth: A Case Study of Jordan", International Journal of Economics and Finance, Vol. 6 No. 3

Dickey, D. A., \& Fuller, W. A. (1979). Distribution of the estimators for autoregressive time series with a unit root. Journal of the American statistical association, 74(366a), 427-431.

Enders, W. (1995). Applied Econometric Time Series, 1995. 
Farahani, Y. G., and Dastan, M. (2013), “Analysis of Islamic Banks' Financing and Economic Growth: A Panel Cointegration Approach", International Journal of Islamic and Middle Eastern Finance and Management, Vol. 6 No. 2 pp. 156-172

Farahani, G., Yazdan and Sadr., and Hossein, S.M. (2012), “Analysis of Islamic Bank's Financing and Economic Growth: Case Study Iran and Indonesia", Journal of Economic Cooperation and Development, Vol. 33 No. 4 pp. 1-24

Financial Service Authority (2015). The Islamic Banking Statistics. Retrieved October 31, 2015, from Financial Service Authority Website: http://www.ojk.go.id/id/kanal/syariah/data-danstatistik/statistik-perbankan-syariah/Default.aspx

Furqani, H., and Mulyany, R. (2009), "Islamic Banking and Economic Growth: Empirical Evidence from Malaysia", Journal of Economic Cooperation and Development", Vol. 30 No. 2 pp. $59-74$

Granger, C. W. (1969). Investigating causal relations by econometric models and cross-spectral methods. Econometrica: Journal of the Econometric Society, 424-438.

Johansen, S. (1988). Statistical analysis of cointegration vectors. Journal of economic dynamics and control, 12(2-3), 231-254.

Newbold, P., \& Granger, C. W. J. (1974). Spurious regressions in econometrics. Journal of Econometrics, 2(2), 111-120.

Ogege, S., and Shiro, A.A. (2012), "Does depositing money in bank impact economic growth? Evidence from Nigeria", African Journal of Business Management, Vol. 7(3) pp. 196-205

Omankhanlen, A.E. (2012), "The Role of Banks in Capital Formation and Economic Growth: The Case of Nigeria", Economy Transdiciplinarity Cognition, Vol. 15 pp. 103-11

Osterwald-Lenum, M. (1992). A note with quantiles of the asymptotic distribution of the maximum likelihood cointegration rank test statistics 1. Oxford Bulletin of Economics and statistics, 54(3), 461-472. 